\title{
BENEFICIAL EFFECTS OF N-ACETYL CYSTEINE ON PANCREAS AND KIDNEY FOLLOWING EXPERIMENTAL PANCREATIC ISCHEMIA- REPERFUSION IN RATS
}

\author{
Roberto Ferreira Meirelles Junior, ${ }^{\mathrm{I}}$ Márcia Saldanha Kubrusly, ${ }^{\mathrm{I}}$ Marta Bellodi- \\ Privato, ${ }^{\mathrm{II}}$ Nilza Aparecida Trindade Molan, ${ }^{\mathrm{I}}$ Marcel Cerqueira Cesar Machado, \\ Luis Augusto Carneiro D'Albuquerque ${ }^{\mathrm{I}}$
}

doi: 10.1590/S1807-59322010000300012

Meirelles Junior R, Kubrusly MS, Bellodi-Privato M, Molan NAT, Machado MCC, D’Albuquerque LAC. Beneficial effects of n-acetyl cysteine on pancreas and kidney following experimental pancreatic ischemia-reperfusion in rats. Clinics. 2010;65(3):311-6.

OBJECTIVE: To evaluate the protective effects of $\mathrm{N}$-acetyl cysteine on the pancreas and kidney after pancreatic ischemia reperfusion injury in a rat model.

METHODS AND MATERIALS: Pancreatic ischemia reperfusion was performed in Wistar rats for 1 hour. Revascularization was achieved followed by $4 \mathrm{~h}$ of reperfusion. A total of 24 animals were divided into four groups: Group 1: sham; Group 2: pancreatic ischemia reperfusion without treatment; Group 3: pancreatic ischemia reperfusion plus N-acetyl cysteine intravenously; and Group 4: pancreatic ischemia reperfusion plus $\mathrm{N}$-acetyl cysteine per os. Blood and tissue samples were collected after reperfusion.

RESULTS: There were significant differences in amylase levels between Group $1(6.11 \pm 0.55)$ and Group $2(10.30 \pm 0.50)$ [p=0.0002] as well as between Group $2(10.30 \pm 0.50)$ and Group $4(7.82 \pm 0.38)$ [p=0.003]; creatinine levels between Group $1(0.52 \pm 0.07)$ and Group $2(0.77 \pm 0.18)[\mathrm{p}=0.035]$ as well as between Group $2(0.77 \pm 0.18)$ and Group $3(0.48 \pm 0.13)$ [p=0.012]; and pancreatic tissue thiobarbituric acid reactive substance levels between Group $1(1.27 \pm 0.96)$ and Group $2(2.60 \pm 3.01)$ [p=0.026] as well as between Group $2(2.60 \pm 3.01)$ and Group $4(0.52 \pm 0.56)$ [p=0.002]. A decrease in pancreatic tissue GST- $\alpha 3$ gene expression was observed in Group 2 in comparison to Group 1 ( $\mathrm{p}=0.006)$, and an increase was observed in Groups 3 and 4 when compared to Group 2 ( $\mathrm{p}=$ 0.025 and $\mathrm{p}=0.010$, respectively).

CONCLUSION: This study provides evidence that $\mathrm{N}$-acetyl cysteine has a beneficial effect on pancreatic ischemia reperfusion injury and renal function in a rat model.

KEYWORDS: N-Acetyl Cysteine; Pancreas; Ischemia; Reperfusion; Transplantation.

\section{INTRODUCTION}

Simultaneous pancreas-kidney transplantation has become the first treatment option for type I diabetes patients with end stage renal failure. ${ }^{1}$ Despite substantial advancements in surgical technique, better

\footnotetext{
I Department of Gastroenterology, Faculdade de Medicina da Universidade de São Paulo - São Paulo/SP, Brazil.

II Department of Pathology, Faculdade de Medicina da Universidade de São Paulo - São Paulo/SP, Brazil.

Tel.: 55113061.8319

Received for publication on November 24, 2009

Accepted f or publication on December 17, 2009
}

immunosuppressive protocols, and improvements in organ preservation solutions, ischemia reperfusion (I-R) injury remains one of the biggest obstacles in the field of solid organ transplantation. ${ }^{2}$ For pancreas transplantation, severe I-R injury provokes graft pancreatitis, which remains a frequent complication $(35 \%)$ in the immediate postoperative time and may contribute to graft loss and kidney injury. ${ }^{3,4}$ Indeed, restrictive donor selection criteria for pancreas transplantation have been applied to avoid acute graft pancreatitis, thus contributing to lower pancreas graft availability and fewer pancreas transplantations.

One of the principle findings in I-R injury is the deterioration of graft microcirculation. The microcirculatory 
derangements are accompanied by an increase in acinar cell apoptosis, and at a later stage, acinar cell necrosis. Different therapeutic strategies, such as nitric oxide donation and endothelin inhibition, antioxidant therapies, anti-adhesive strategies, ischemic preconditioning, inhibition of apoptosis, and anti-inflammatory treatment have been established to counteract the effects of I-R injury. ${ }^{2}$

Free radical scavengers attenuate I-R injury by eliminating the reactive oxygen species (ROS) that are well known to play a major role in the progression of I-R injuryinduced graft damage. ${ }^{5,6}$

$\mathrm{N}$-acetyl cysteine (NAC) has been shown to improve pancreatic microcirculation alterations in experimental pancreas transplantation. ${ }^{7}$ NAC interferes with ROS production by inhibiting active granulocytes, and it acts as a scavenger and induces glutathione production. ${ }^{8}$ Also, little is known about the gene expression underlying these actions in pancreatic I-R injury, not only in the pancreas but also in the kidney. Glutathione-S-transferase (GST) enzymes provide protection against neutrophils and ROS by catalyzing the formation of glutathione conjugates as well as by eliminating peroxides during I-R injury. ${ }^{9}$ Therefore, analysis of GST gene expression in this condition should help to reveal the mechanisms by which NAC protects the pancreas during I-R injury.

The aim of this study was to evaluate the protective mechanisms of NAC in the pancreas and kidney after pancreatic I-R injury in a rat model.

\section{METHODS AND MATERIALS}

The experimental model protocol and animal handling as well as procedures were performed in accordance with Faculdade de Medicina da Universidade de São Paulo Committee of Ethics in Research. Before the procedure, all animals had a 12-hour fasting period except for water given ad libitum.

Twenty-four Wistar rats weighing 300-350 g were anesthetized using Ketalar $^{\circledR} / x y l a z i n e ~ s o l u t i o n$ (initial dose of $170 \mathrm{mg} / \mathrm{kg}$ ). During the procedure, anesthesia was maintained by intraperitoneal infusion of $\operatorname{Ketalar}^{\circledR} / x^{\infty}$ lazine solution (dose of $85 \mathrm{mg} / \mathrm{kg} / \mathrm{h}$ ) throughout the experiment.

Animals were intubated using a 14-gauge catheter and connected to volume-controlled ventilation (Harvard ventilator). The right jugular vein was cannulated using PE-50 tubing.

\section{Pancreatic ischemia-reperfusion model}

A pancreatic I-R model was established as described elsewhere. ${ }^{10}$ Briefly, the abdomen was opened by a midline laparotomy. The stomach was turned up cranially by two stay sutures. The splenic pancreas portion was carefully separated from the stomach, and the short gastric vessels were ligated. The spleen was used as a grip to move the pancreatic tail to minimize pancreatic injury. Some arterial arcades from the inferior pancreaticoduodenal artery to the splenic artery were ligated. Thus, a complete pedunculated pancreatic tail by splenic vessels was achieved. A vascular clamp was applied to the splenic vessels. The pancreatic tail portion was submitted to ischemia for $1 \mathrm{~h}$. After completing $1 \mathrm{~h}$ of ischemia, the vascular clamp was removed, and pancreatic revascularization was achieved followed by $4 \mathrm{~h}$ of reperfusion. The abdominal wall remained closed during the I-R period. Blood and tissue samples (pancreas and kidney) were collected after $4 \mathrm{~h}$ of reperfusion.

\section{Experimental protocol}

The animals were divided into four groups:

- Group 1 ( $\mathrm{n}=6)$ : sham (submitted to operative procedure without pancreatic I-R);

- Group 2 ( $n=6)$ : I-R (submitted to pancreatic I-R procedure without treatment);

- Group 3 (n=6): I-R plus NAC - intravenously (iv): submitted to pancreatic I-R procedure and received NAC iv $150 \mathrm{mg} / \mathrm{kg} 15$ minutes before reperfusion and maintained at $50 \mathrm{mg} / \mathrm{kg} / \mathrm{h}$ during $4 \mathrm{~h}$ of reperfusion; and

- Group 4 ( $\mathrm{n}=6)$ : I-R plus NAC - per os (po): submitted to pancreatic I-R procedure and received NAC $4800 \mathrm{mg} / \mathrm{L}$ ad libitum $48 \mathrm{~h}$ before the experiment.

\section{Serum amylase and creatinine levels and pancreatic TBARS}

Serum samples were assayed for amylase and creatinine levels. ${ }^{11}$

Pancreatic tissue thiobarbituric acid reactive substance (TBARS) levels were determined as previously described. ${ }^{12}$ Malondialdehyde (MDA) levels in the samples were determined to obtain a quantitative estimate of membrane lipid oxidative damage. MDA was assayed in terms of thiobarbituric acid reactive substances. Pancreas tissues (100 mg/mL) were homogenized in $1.15 \% \mathrm{KCl}$ buffer and centrifuged at $14,000 \mathrm{x}$ g for $20 \mathrm{~min}$. The supernatant was then stored at $-80^{\circ} \mathrm{C}$. An aliquot of the supernatant was added to a reaction mixture of $1.5 \mathrm{~mL} 0.8 \%$ thiobarbituric acid, $200 \mu \mathrm{L} 8.1 \%$ (v/v) SDS, $1.5 \mathrm{~mL} 20 \%$ (v/v) acetic acid, $\mathrm{pH} 3.5$, and $300 \mu \mathrm{L}$ distilled $\mathrm{H}_{2} \mathrm{O}$ and heated to $90^{\circ} \mathrm{C}$ for 45 min. After cooling to room temperature, the samples were cleared by centrifugation at $10,000 \mathrm{x} \mathrm{g}$ for $10 \mathrm{~min}$, and their absorbance was measured at $532 \mathrm{~nm}$ using malondialdehyde 
bis (dimethyl acetal) as an external standard. The quantity of lipid peroxides is reported in nmol malondialdehyde (MDA) equivalents/mg protein.

\section{RNA isolation}

Total RNA was isolated from pancreas and kidney using Trizol reagent (Invitrogen, Life Technologies, Gaithersburg, USA) according to the manufacturer's instructions from fresh-frozen pancreas and kidney tissues from all groups. RNA quality assessment was analyzed with an aliquot of $500 \mathrm{ng}$ on a $1 \%$ agarose gel. Samples were kept at $-80^{\circ} \mathrm{C}$ until processing by quantitative RT-PCR (qRT-PCR).

\section{GST- $\alpha 3$ quantitative RT-PCR analysis}

qRT-PCR analysis was performed in the Rotor-Gene RG-3000 (Corbett Research, Sidney, Australia) using the SuperScript ${ }^{\mathrm{TM}}$ III Platinum ${ }^{\circledast}$ SYBR $^{\circledR}$ Green One-Step qRT-PCR kit (Invitrogen, Life Technologies) with 100 ng of total RNA and $0.2 \mu \mathrm{M}$ sense/antisense primer per reaction, according to the manufacturer's recommendations. The reaction was carried out under the following cycling conditions: $10 \mathrm{~min}$ at $50^{\circ} \mathrm{C}$ and $5 \mathrm{~min}$ at $95^{\circ} \mathrm{C}$ followed by 35 cycles of $20 \mathrm{sec}$ at $95^{\circ} \mathrm{C}, 30 \mathrm{sec}$ at $57^{\circ} \mathrm{C}$ and $30 \mathrm{sec}$ at $72^{\circ} \mathrm{C}$. To verify amplification reaction specificity, melting curves were determined using the following parameters: $72^{\circ} \mathrm{C}$ ramping to $99^{\circ} \mathrm{C}$ at $0.2^{\circ} \mathrm{C} / \mathrm{s}$. Primer sets were designed to amplify two separate intron-spanning regions, enabling assessment for possible genomic DNA contamination: GST- $\alpha 3$ sense $5^{\prime}$-GGC GGA TCT GGA TGA AAT AGT TCT-3'; GST- $\alpha 3$ antisense 5'-CAA CGA GAT AAT CTT GTC CAT GGC-3'; $\beta$-actin sense $5^{\prime}$-TGT CAC CAA CTG GGA CGA TA-3'; and $\beta$-actin antisense $5^{\prime}$-GGG GTG TTG AAG GTC TCA AA-3'. Primers were designed using the primer3_www.cgi v 0.2 program. ${ }^{13}$ Specificity of the product was ensured by melting point analysis and agarose gel electrophoresis to visualize the band for GST- $\alpha 3$ and $\beta$-actin with the corresponding sizes: $152 \mathrm{bp}$ and $165 \mathrm{bp}$, respectively. RNA template concentrations $(500 \mathrm{ng} / \mu \mathrm{l}, 100$ $\mathrm{ng} / \mu \mathrm{l}, 20 \mathrm{ng} / \mu \mathrm{l}, 4 \mathrm{ng} / \mu \mathrm{l}$ and $0.8 \mathrm{ng} / \mu \mathrm{l})$ were used to generate a standard curve to evaluate the amplification efficiency of the GST- $\alpha 3$ gene in comparison to $\beta$-actin. The RNA content of GST- $\alpha 3$ was determined as the number of transcripts relative to those of $\beta$-actin and additionally normalized to the mean value of control pancreas and kidney. Relative quantification was calculated using a mathematical model based on GST- $\alpha 3$ and $\beta$-actin gene amplification efficiency. ${ }^{14}$ All samples were analyzed in duplicate.

\section{Statistical Analysis}

The results were expressed as arithmetic mean and standard deviation (sd). Collected data were stored in a computer, plotted using spreadsheets in the Excel program (Microsoft, Seattle, WA, USA) and statistically analyzed using GraphPad Prism 2.01 (San Diego, CA, USA), JMP Starter 5.1.1. (SAS Institute Inc., Heidelberg, Germany) and SigmaStat 2.03 Statistical (Systat Software Inc., Point Richmond, USA). The differences between the mean values were compared by Student's $t$-test for unpaired data and analysis of variance (ANOVA) with comparisons using the Kruskal-Wallis test based on rank sum. A P value of less than 0.05 was considered statistically significant.

\section{RESULTS}

Serum amylase levels were $6.11 \pm 0.55 \mathrm{mg} / \mathrm{mL} / \mathrm{min}$, $10.30 \pm 0.50 \mathrm{mg} / \mathrm{mL} / \mathrm{min}, 9.77 \pm 1.24 \mathrm{mg} / \mathrm{mL} / \mathrm{min}$ and $7.82 \pm 0.38 \mathrm{mg} / \mathrm{mL} / \mathrm{min}$ in Groups 1, 2, 3 and 4, respectively. There was an increase in serum amylase when comparing Group 1 with Group $2(\mathrm{p}=0.0002)$ and a decrease when comparing Group 2 with Group $4(\mathrm{p}=0.003)$ (Table 1).

Serum creatinine levels were $0.52 \pm 0.07 \mathrm{mg} / \mathrm{dL}$, $0.77 \pm 0.18 \mathrm{mg} / \mathrm{dL}, 0.48 \pm 0.13 \mathrm{mg} / \mathrm{dL}$ and $0.83 \pm 0.25 \mathrm{mg} / \mathrm{dL}$ for Groups 1, 2, 3 and 4, respectively. There was an increase in serum creatinine when comparing Group 1 with Group $2(\mathrm{p}=0.035)$ and a decrease when comparing Group 2 with Group 3 ( $\mathrm{p}=0.012$ ) (Table 1).

Pancreatic tissue TBARS levels were $1.27 \pm 0.96 \mathrm{nmol}$ TBARS/mg protein, $2.60 \pm 3.01 \mathrm{nmol}$ TBARS/mg protein, $1.44 \pm 1.61 \mathrm{nmol}$ TBARS/mg protein, and $0.52 \pm 0.56 \mathrm{nmol}$

Table 1 - Amylase and creatinine serum levels and TBARS pancreatic tissue expressed as mean \pm standard deviation.

\begin{tabular}{lccc}
\hline Group & Amylase (mg/mL/min) & Creatinine (mg/dL) & TBARS (nmol/protein/mg) \\
\hline 1 & $6.11 \pm 0.55^{\mathrm{a}}$ & $0.52 \pm 0.07^{\mathrm{c}}$ & $1.27 \pm 0.96^{\mathrm{e}}$ \\
2 & $10.3 \pm 0.5^{\mathrm{a}, \mathrm{b}}$ & $0.77 \pm 0.18^{\mathrm{c}, \mathrm{d}}$ & $2.60 \pm 3.01^{\mathrm{e}, \mathrm{f}}$ \\
3 & $9.77 \pm 1.24$ & $0.48 \pm 0.13^{\mathrm{d}}$ & $1.44 \pm 1.61$ \\
4 & $7.82 \pm 0.38^{\mathrm{b}}$ & $0.83 \pm 0.25$ & $0.52 \pm 0.56^{\mathrm{f}}$ \\
\hline
\end{tabular}

a- $p=0.0002 ; b-p=0.003 ; c-p=0.012 ; d-p=0.03 ; e-p=0.0023 ; f-p=0.026$ 


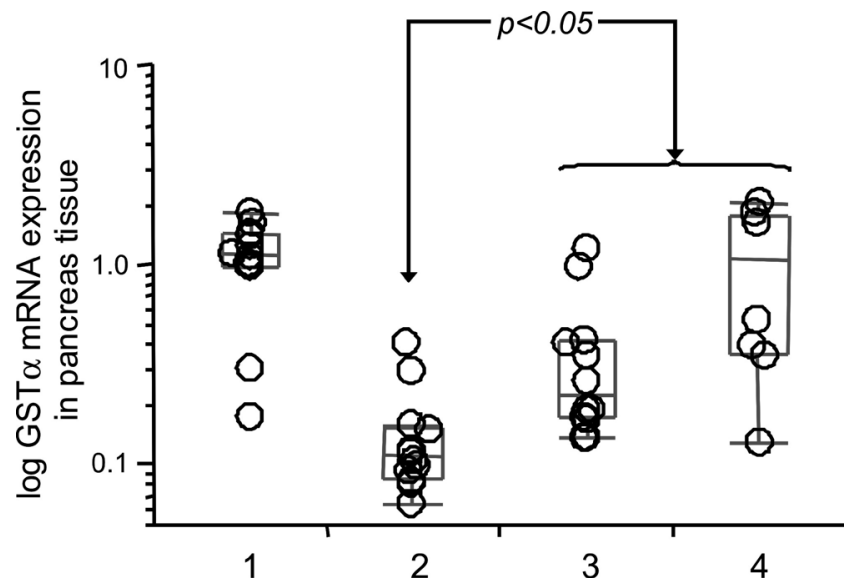

Figure 1 - Box diagram comparing relative GST- $\alpha 3$ mRNA expression levels in pancreas tissues in Groups 1,2,3 and 4. The horizontal line within the box plot represents the median value, the box plot limits refer to 25 th to 75th percentiles, and the box plot bars include the 10th to 90th percentiles for mRNA levels.

TBARS/mg protein for Groups 1, 2, 3 and 4, respectively. There was an increase in pancreatic tissue TBARS levels when comparing Group 1 with Group $2(\mathrm{p}=0.026)$ and a decrease when comparing Group 2 with Group $4(\mathrm{p}=0.002)$ (Table 1).

A decrease in pancreatic tissue GST- $\alpha 3$ gene expression was observed in Group 2 compared to Group $1(\mathrm{p}=0.006)$, and an increase was observed in Groups $3(\mathrm{p}=0.025)$ and 4 $(\mathrm{p}=0.010)$ when compared to Group 2 (Figure 1).

An increase in renal tissue GST- $\alpha 3$ gene expression was observed in Group 2 compared to Group 1 ( $\mathrm{p}=0.037$ ), and a decrease was observed in Group 4 when compared to Group $2(\mathrm{p}=0.010)$ (Figure 2).

\section{DISCUSSION}

NAC, a precursor of 1-cysteine and reduced glutathione (GSH), affects a variety of biological and pathological processes, as it is a source of sulfhydryl groups in cells and a ROS scavenger. Numerous studies have shown a protective effect of free radical scavengers such as NAC, glutathione, and others on I-R injury. ${ }^{15}$

In our experiment, pancreatic I-R injury promoted hyperamylasemia. Pancreatic I-R injury has been known to produce hyperamylasemia probably due to ROS damage. Tamura et al. suggested that the active oxygen species that are generated by short-term pancreatic ischemia and reperfusion injure the endothelium and cause hyperamylasemia. Inhibition of the increase in serum amylase concentration by pretreatment with a scavenger of active oxygen, superoxide dismutase, suggests that the active oxygen species are involved in the pathogenesis of acute pancreatitis. ${ }^{16}$ Our results showed that NAC given 48

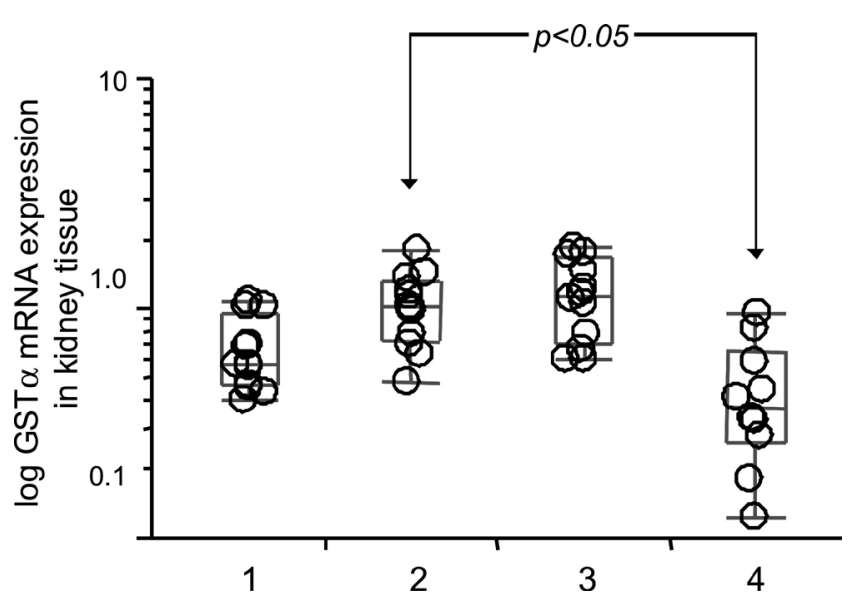

Figure 2 - Box diagram comparing relative GST- $\alpha 3$ mRNA expression levels in kidney tissues in Groups 1, 2, 3 and 4. The horizontal line within the box plot represents the median value, the box plot limits refer to 25 th to 75th percentiles, and the box plot bars include the 10th to 90th percentiles for mRNA levels.

$\mathrm{h}$ before I-R induction reduced the amylasemia. However, iv NAC given during pancreatic I-R induction was unable to reduce the amylasemia.

It is known that many immediate-early genes are expressed during I-R injury. ${ }^{17,18}$ We demonstrated that reduced pancreatic GST- $\alpha 3$ gene expression may be due to blood flow interruption with a subsequent impairment of antioxidant protective mechanisms. However, a renal GST- $\alpha 3$ gene expression increase by itself was unable to preserve renal function as demonstrated by creatinine levels (Table 1). Interestingly, renal function was improved only by iv NAC. This protective effect may be due to a higher blood level achieved by iv NAC and its direct hydroxyl radical scavenging ability. ${ }^{19,20}$ In a chronic renal failure model, experimental NAC administration has been shown to have a renal protective effect attributable to lower lipid peroxidation levels. ${ }^{21}$

Several antioxidants (e.g., mannitol, allopurinol, $\mathrm{N}$-acetyl-cysteine) were shown to reduce the negative effect of xanthine oxidase on remote organs by scavenging hydroxyl radicals and reducing the oxidant-derived injury. ${ }^{22,23}$ Khoury et al. examined the effect of I-R of the rat pancreas on rat kidney function in an isolated organ model. The authors assessed whether the level of oxidative stress detected during pancreas I-R would correlate with the use of mannitol (an antioxidant and a clinically used compound) in such occasions, i.e., the prevention of kidney dysfunction. They showed that ischemia/reperfusion of the rat pancreas evokes immediate renal dysfunction and that kidney oxidant-antioxidant balance is disturbed; however, this can be prevented with mannitol. ${ }^{24}$

NAC also may exert its antioxidant effects by reducing lipid peroxidation, thus attenuating membrane damage 
from ROS. It was associated with pancreatic GST- $\alpha 3$ gene expression. In our experiment, NAC provided effective pancreatic protection against I-R injury, as revealed by lower serum TBARS and amylase levels, an increase in GST- $\alpha 3$ expression and a decrease in pancreatic tissue TBARS. However, it did not recover renal function nor increase renal GST- $\alpha 3$ gene expression.

There are numerous potential mechanisms of action by which NAC may exert protective effects against I-R injury. These potential protective effects of NAC have been tested in several animal models, including models in which animals were subjected to hepatic ischemia with hepatic vascular inflow occlusion followed by reperfusion and in animals that were subjected to liver transplantation. Overall, these studies have demonstrated that NAC was able to maintain hepatic GSH levels when administered prior to I-R and was effective at replenishing depleted glutathione stores rapidly when administered after I-R. ${ }^{25-27}$

The oxidative stress generated by the imbalance between ROS and the endogenous antioxidant forces is now known to be closely related to renal I-R injury. In addition to being the precursor of L-cysteine and glutathione reductase, NAC acts as a superoxide scavenger and is capable of tripling endothelial NOS expression as well as increasing NO bioavailability. ${ }^{28,29} \mathrm{~N}$-acetylcysteine may also be protective through its influence on the metabolism of $\mathrm{NO}$, which is produced in large amounts in the setting of liver I-R injury due to the expression of inducible NO synthetase (iNOS)..$^{30}$

In summary, our study demonstrates that NAC administration ameliorates the pancreatic I-R injury observed $4 \mathrm{~h}$ after reperfusion. Although we have shown the beneficial action of NAC in pancreatic I-R injury, further studies are still needed to support these findings.

\section{REFERENCES}

1. Robertson P, Davis C, Larsen J, Stratta R, Sutherland DE. Pancreas transplantation in type 1 diabetes; American Diabetes Association. Diabetes Care. 2004;27 (Suppl 1): S105

2. Drognitz O, Benz S, Pfeffer F, Fischer C, Makowiec F, Schareck W, et al. Long-term follow-up of 78 simultaneous pancreas-kidney transplants at a single-center institution in Europe. Transplantation. 2004;78:1802-8.

3. Fernández-Cruz L, Sabater L, Gilabert R, Ricart MJ, Saenz A, Astudillo E. Native and graft pancreatitis following combined pancreas-renal transplantation. Br J Surg. 1993;80:1429-32.

4. Sutherland DE. State of the art in pancreas transplantation. Transplant Proc. 1994;26:316-20

5. Steib A, Freys G, Collin F, Launoy A, Mark G, Boudjema K. Does $\mathrm{N}$-acetylcysteine improve hemodynamics and graft function in liver transplantation? Liver Transpl Surg. 1998;4:152-7.

6. Lin A, Sekhon C, Sekhon B, Smith A, Chavin K, Orak J, et al. Attenuation of ischemia-reperfusion injury in a canine model of autologous renal transplantation. Transplantation. 2004;78:654-9.

7. Mayer H, Thies J, Schmidt J, Gebhard MM, Herfarth C, Klar E. Decreasing reperfusion damage with $\mathrm{N}$-acetylcysteine in experimental pancreas transplantation. Langenbecks Arch Chir Suppl Kongressbd. 1998;115:147-51.

8. Millar AD, Rampton DS, Chander CL, Claxson AW, Blades S, Coumbe A, et al. Evaluating the antioxidant potential of new treatments for inflammatory bowel disease using a rat model of colitis. Gut. 1996;39:407-15

9. Hayes JD, Flanagan JU, Jowsey IR. Glutathione transferases. Annu Rev Pharmacol Toxicol. 2005;45:51-88.

10. Dembiński A, Warzecha Z, Ceranowicz P, Stachura J, Tomaszewska R, Konturek SJ, et al. Pancreatic damage and regeneration in the course of ischemia-reperfusion induced pancreatitis in rats. J Physiol Pharmacol. 2001;52:221-35
11. Jamieson AD, Pruitt KM, Caldwell RC. An improved amylase assay. J Dent Res. 1969;48:483.

12. Soriano FG, Liaudet L, Szabó E, Virág L, Mabley JG, Pacher P, et al. Resistance to acute septic peritonitis in poly(ADP-ribose) polymerase1-deficient mice. Shock. 2002;17:286-92.

13. Rozen S, Skaletsky H. Primer3 on the WWW for general users and for biologist programmers. Methods Mol Biol. 2000;132:365-86.

14. Pfaffl MW. A new mathematical model for relative quantification in real-time RT-PCR. Nucleic Acids Res. 2001;29 (9):e45.

15. Sagristá ML, García AE, Africa De Madariaga M, Mora M. Antioxidant and pro-oxidant effect of the thiolic compounds $\mathrm{N}$-acetyl-L-cysteine and glutathione against free radical-induced lipid peroxidation. Free Radic Res. 2002;36:329-40

16. Tamura K, Manabe T, Kyogoku T, Andoh K, Ohshio G, Tobe T. Effect of postischemic reperfusion on the pancreas. Hepatogastroenterology. $1993 ; 40: 452-6$

17. Benz S, Löbler M, Obermaier R, Kortmann B, Pfeffer F, Koczan D, et al. New possible target genes in pancreatic ischemia/reperfusion-injury identified by microarray analysis. Transplant Proc. 2002;34:2369-71.

18. Drognitz O, Michel P, Koczan D, Neeff H, Mikami Y, Obermaier R, et al. Characterization of ischemia/reperfusion-induced gene expression in experimental pancreas transplantation. Transplantation. 2006;81:142834.

19. Brunet J, Boily MJ, Cordeau S, Des Rosiers C. Effects of N-acetylcysteine in the rat heart reperfused after low-flow ischemia: evidence for a direct scavenging of hydroxyl radicals and a nitric oxide-dependent increase in coronary flow. Free Radic Biol Med. 1995;19:627-38.

20. Cabassi A, Dumont EC, Girouard H, Bouchard JF, Le Jossec M, Lamontagne D, et al. Effects of chronic N-acetylcysteine treatment on the actions of peroxynitrite on aortic vascular reactivity in hypertensive rats. J Hypertens. 2001;19:1233-44. 
21. Shimizu MH, Coimbra TM, de Araujo M, Menezes LF, Seguro AC. $\mathrm{N}$-acetylcysteine attenuates the progression of chronic renal failure. Kidney Int. 2005;68:2208-17.

22. Weinbroum A, Nielsen VG, Tan S, Gelman S, Matalon S, Skinner KA, et al. Liver ischemia-reperfusion increases pulmonary permeability in rats: Role of circulating xanthine oxidase. Am J Physiol. 1995;268: G988-96.

23. Haraldsson G, Sorensen V, Nilsson U, Pettersson S, Rashid M, Scherstén $\mathrm{T}$, et al. Effect of pretreatment with desferrioxamine and mannitol on radical production and kidney function after ischemia-reperfusion. A study on rabbit kidneys. Acta Physiol Scand. 1995;154:461-8.

24. Khoury W, Namnesnikov M, Fedorov D, Abu-Ghazala S, Weinbroum AA. Mannitol attenuates kidney damage induced by xanthine oxidaseassociated pancreas ischemia-reperfusion. J Surg Res. Dec 30. [Epub ahead of print].

25. Fukuzawa K, Emre S, Senyuz O, Acarli K, Schwartz ME, Miller CM. $\mathrm{N}$-acetylcysteine ameliorates reperfusion injury after warm hepatic ischemia. Transplantation. 1995;59:6-9.
26. Demir S, Inal-Erden M. Pentoxifylline and $\mathrm{N}$-acetylcysteine in hepatic ischemia/reperfusion injury. Clin Chim Acta. 1998;275:127-35.

27. Sener G, Tosun O, Sehirli AO, Kacmaz A, Arbak S, Ersoy Y, et al. Melatonin and $\mathrm{N}$-acetylcysteine have beneficial effects during hepatic ischemia and reperfusion. Life Sci. 2003;72:2707-18.

28. Majano PL, Medina J, Zubia I, Sunyer L, Lara-Pezzi E, MaldonadoRodriguez A, et al. N-Acetyl-cysteine modulates inducible nitric oxide synthase gene expression in human hepatocytes. J Hepatol. 2004;40:632-

29. Caglikulekci M, Pata C, Apa DD, Dirlik M, Tamer L, Yaylak F, et al. The effect of $\mathrm{N}$-acetylcysteine (NAC) on liver and renal tissue inducible nitric oxide synthase (iNOS) and tissue lipid peroxidation in obstructive jaundice stimulated by lipopolysaccharide (LPS). Pharmacol Res. 2004;49:227-38

30. Glantzounis GK, Rocks SA, Sheth H, Knight I, Salacinski HJ, Davidson $\mathrm{BR}$, et al. Formation and role of plasma S-nitrosothiols in liver ischemiareperfusion injury. Free Radic Biol Med. 2007; 42:882-92. 